\title{
NALAR PEREMPUAN \\ Upaya Rekonstruksi Konstruksi Sosial Setara Gender
}

\author{
Fauzi Ahmad Muda \\ Peneliti pada The Pesantren Institute, Malang
}

\begin{abstract}
Abstrak
Historical notes of women (1400 years ago) reveal that they lived in prosperous and happy condition socially as well as materially. Women's condition, by that time, was better than recent west women's condition (not to compare the way they wear clothes and their life style). Nonetheless, Moslem community recently flies with one wing as its human resource (especially women) has not been educated well. Then, why should we bind women in private area?
\end{abstract}

\section{A. PENDAHULUAN}

Dalam tatanan kehidupan sosial masyarakat kita sekarang -dan bisa dikatakan sejak zaman dahulu- perempuan kerap diasumsikan sebagai kelompok gender yang lemah, bukan hanya dalam arti fisik an sich, tetapi juga secara psikologis, mental dan spiritual. Perempuan diasumsikan sebagai makhluk yang lembut dan penuh perasaan, berbeda dengan laki-laki yang berwatak keras, tegas dan berfikir lebih rasional.

Laki-laki pantang menangis, tetapi bagi perempuan tangisan diajarkan sebagai sebuah kewajaran, bahkan tidak sedikit yang menuduh, menangis adalah senjata perempuan. Karena itu, muncullah anggapan bahwa watak dasar perempuan seperti itu yang menyebabkan mereka harus tunduk kepada laki-laki. Laki-laki adalah pelindung dan pembimbingnya.

Sejak masa kecilnya, anak-anak perempuan telah diajari bermimpi dengan dongeng-dongeng semacam Cinderella, Putri Salju, Putri Angsa, Pangeran Kodok, Ande-Ande Lumut atau Bawang Putih Bawang Merah, yang mempercayai bahwa suatu saat pangeran tampan akan datang dan menyelamatkan hidupnya dari lumpur penderitaan dan hidup bahagia selama- 
lamanya. Kesadaran palsu lalu juga terbentuk; bahwa pangeran yang baik hati dan rupawan itu tidak mungkin akan mencederai "sang putri".

Salah satu efek dari kesadaran itu, dalam ilmu psikologi, dikenal istilah sindrom Cinderella Complex, sebuah ketakutan tersembunyi pada perempuan untuk mandiri. Karena yang ada dalam pikiran mereka adalah keinginan untuk selalu diselamatkan, dilindungi, dan tentunya disayangi oleh "sang pangeran". Pada saat yang lain, perempuan sering menciptakan masalah bagi dirinya sendiri, dengan mengatakan "ya" pada sesuatu yang seharusnya dia mengatakan “tidak"; tetapi ketika memaksa dirinya untuk mengatakan "tidak” justru mereka merasa bersalah.

Kedudukan status perempuan yang lemah ini dikuatkan dengan perkembangan berbagai konsep dan teori ilmu-ilmu sosial, seperti antropologi, sosiologi, historiografi dan sebagainya, yang epistemologinya didukung oleh pemahaman keagamaan di dalam masyarakat yang bias gender. Maskulinisasi epistem ini bukan hanya melahirkan ilmu pengetahuan dan teknologi yang sangat memihak kepada laki-laki tetapi juga telah melahirkan kebudayaan dan peradaban yang penuh dengan diskriminasi gender dalam aksiologinya.

Hasilnya, laki-laki dengan segala aspek maskulinitasnya kerap melakukan kekerasan yang menurut mereka sah-sah saja. Dan dalam banyak kasus kekerasan dalam pacaran, lebih-lebih kekerasan dalam rumah tangga, misalnya, perempuan cenderung mentolerir perbuatan pasangannya karena percaya bahwa atas nama cinta, semua dapat berubah, kekerasan -apapun bentuknya- yang dilakukan pasangannya tidak akan terulang lagi. Perempuan juga disosialisasikan untuk selalu tunduk pada pasangannya, bahkan ketika masih dalam tahap berpacaran. Hal itu terpatrikan jauh di alam bawah sadar perempuan. Disinilah laki-laki pelaku kekerasan biasanya lantas memanfaatkan kata-kata cinta untuk meleburkan hati, namun dalam kesempatan lain mereka kembali "memukul".

Dalam kenyataan hidup sehari-hari, di sekitar kita juga tidak jarang kita dengar, perempuan dinasehati untuk patuh kepada suaminya, dan laki-laki tidak boleh sekali-kali tunduk kepada istrinya. Sebuah ironi yang sangat menyedihkan. Laki-laki seakan telah kebal dan maksum atas segala kesalahan yang dibuatnya. 
Kemudian, perempuan selalu diingatkan untuk sabar dan tabah atas segala kekeliruan suaminya, sementara kepada laki-laki dinasihati agar tidak pernah kalah atau sekedar mengalah menghadapi perempuan. Hal ini sesungguhnya sangat bertentangan dengan pesan al-Qur'an, karena yang diingatkan justru sebaliknya (laki-laki). ${ }^{1}$

Dalam perspektif teologi terdapat empat faktor yang berpotensi menjadi faktor penting dalam mempengaruhi pembentukan anggapan stereotip terhadap perempuan. Pertama, anggapan bahwa perempuan tercipta hanya sebagai pelengkap hasrat dan keinginan Adam di surga, menjadikan perempuan tidak lebih sebagai pelengkap keinginan laki-laki. Kedua, tempat di mana manusia pertama telah diciptakan yaitu surga, telah melahirkan pelbagai mitos yang merendahkan perempuan. Ketiga, anggapan bahwa perempuan tercipta dari tulang rusuk Adam, berhasil meletakkan kedudukan perempuan lebih rendah dari laki-laki. Keempat, anggapan bahwa godaan perempuanlah yang menyebabkan terusirnya Adam (dan Hawa) dari surga ke bumi dalam satu drama kosmik yang melegenda dan digiring menjadi mitos. Anggapan ini telah melahirkan konsep ‘dosa warisan’ yang dibebankan kepada perempuan.

Empat persoalan teologi ini melahirkan pandangan misoginis yang merugikan perempuan. Tradisi pemahaman keagamaan seperti ini diturunkan kepada tradisi intelektual dunia Islam melalui perhubungan Islam dengan budaya Yunani, Hellenisme, Sasanid-Parsi, Yahudi, Nasrani dan juga warisan budaya yang dipengaruhi Majusi dan Zoroaster.

Menurut Prof. Nasaruddin Umar, budaya di berbagai tempat, hubungan tertentu antara laki-laki dan perempuan dikonstruksi oleh mitologi. Mulai dari mitos perempuan yang tercipta dari tulang rusuk laki-laki, sampai mitos-mitos di sekitar menstruasi. Mitologi-mitologi ini terkesan cenderung menempatkan perempuan sebagai makhluk the second creation atau the second sex. Pengaruh

\footnotetext{
1 "Hai orang-orang yang beriman, tidak halal bagi kamu mempusakai perempuan dengan jalan paksa dan janganlah kamu menyusabkan mereka karena bendak mengambil kembali sebagian dari apa yang telab kamu berikan kepadanya, terkecuali bila mereka melakukan pekerjaan keji yang nyata. Dan bergaullah dengan mereka secara patut. Kemudian bila kamu tidak menyukai mereka, (maka bersabarlab), karena mungkin kamu tidak menyukai sesuatu, padahal Allah menjadikan padanya kebaikan yang banyak." (QS. al-Nisa': 19).

"Dan di antara tanda-tanda kekuasaan-Nya ialah Dia menciptakan untukmu istri-istri dari jenismu sendiri, supaya kamu cenderung dan merasa tenteram kepadanya, dan dijadikan-Nya diantara kamu rasa kasib dan sayang. Sesungguhnya pada yang demikian itu benar-benar terdapat tanda-tanda bagi kaum yang berfikir." (QS. al-Rum: 21).
} 
mitos-mitos tersebut, kini telah mengendap di bawah alam sadar perempuan sekian lama, sehingga perempuan menerima kenyataan dirinya sebagai

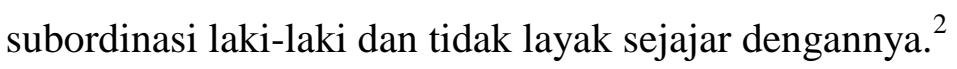

Laela Ahmed, dalam bukunya Women and Gender in Islam: Historical Roots of a Modern Debate, melakukan penelitian terhadap pemahaman teologis dari mitologi perempuan yang dianggap sebagai akar historis pemahaman misoginis. Pemahaman bahwa perempuan dianggap rendah dan hanya menjadi subordinasi laki-laki telah ada sejak zaman Hammurabi dan zaman Assyria. Bahkan praktik perkawinan incest bukan hanya di toleransi, tetapi juga dipandang sebagai amal kesalehan. ${ }^{3}$ Demikianlah pemahaman tentang penciptaan perempuan di masa lalu, yang hingga kini sebenarnya masih subur dalam kepercayaan kita, yang tercipta atas arogansi laki-laki.

Tumbuhnya budaya dan perilaku diskriminatif dan patriarkhis di dalam masyarakat secara nyata telah memarginalkan perempuan hampir dalam segala relung-relung kehidupan. Maraknya wacana dan gerakan-gerakan tentang kesetaraan gender -dalam konteks Indonesia- tidak lepas dari kondisi riil yang ditemukan dalam masyarakat, misalnya masih kuatnya kultur patriakhi, ketidakadilan gender, diskriminasi, penindasan maupun kekerasan terhadap perempuan baik dalam ruang pribadi maupun sosial, privat maupun publik.

Upaya-upaya pemberdayaan perempuan sudah banyak dilakukan, namun masih banyak kendala yang menghadang. Salah satu kendalanya adalah masih kuatnya interpretasi ajaran yang menempatkan perempuan sebagai subordinat laki-laki, bukan sebagai mitra sejajar. Hal ini bisa dipahami mengingat masyarakat Indonesia yang patriarkhis dan religius masih sangat kokoh memegang ajaran-ajaran agamanya, dalam arti interpretasi ajaran.

Yang perlu disadari, bahwa agama yang sering kita bicarakan ini sesungguhnya lebih merupakan aktualisasi dari pemahaman kita terhadap kehendak Tuhan yang teramat dalam dan tak terperikan. Artinya, yang kita perbincangkan itu tidak lain adalah tafsiran, interpretasi atau ikhtiar manusiawi

${ }^{2}$ NasaruddIn Umar, Argumen kesetaraan Gender Perspektif al-Qur'an, Jakarta: Paramadina, 1999,88. ${ }^{3}$ Laela Ahmed, Wanita dan Gender dalam Islam. Akar-akar Historis Perdebatan Modern, Jakarta: Lentera, 2000,5-41. 
untuk menemukan makna dari pesan-pesan Tuhan yang telah diturunkan, sementara hakikat dari kehendak Tuhan tersebut tetap penuh misteri.

Sumber pokok ajaran Islam adalah al-Qur'an dan Hadits, tetapi penafsiran terhadap kedua sumber tersebut berbeda-beda antara satu ulama dengan ulama yang lainnya. Akan tetapi, perbedaan pendapat dalam menafsirkan firman Tuhan dan Hadits Nabi bukanlah hal yang perlu membuat kita gusar dan takut. Tanpa perbedaan pendapat, dunia ini akan kehilangan dinamika.

Pembacaan teks-teks keagamaan melalui pendekatan kontekstual merupakan cara yang paling sesuai untuk memahami teks-teks tersebut secara benar dan proporsional agar sejalan dengan tujuan-tujuan syari'ah. Pendekatan ini juga sangat relevan untuk menjawab masalah-masalah kehidupan yang terus berkembang, termasuk masalah hubungan antara laki-laki dan perempuan yang masih timpang (bias gender). Selain itu, yang perlu ditekankan dalam konteks ini adalah agar kita tidak terbiasa mengklaim bahwa penafsiran kita yang paling benar sementara penafsiran yang lain adalah tidak benar, bahkan salah. Karena tidak seorang pun mempunyai otoritas bahwa penafsirannya benar sementara memfatwakan penafsiran yang lain salah, karena kebenaran tidak dapat dimonopoli oleh seseorang atau suatu golongan. Islam berdiri atas dasar fondasi menghormati perbedaan.

\section{B. PEREMPUAN DAN TANGGUNG JAWAB KEMANUSIAAN}

Fakta kehidupan dalam masyarakat adalah akar sejarah panjang dominasi laki-laki atas perempuan, dimana hampir dalam semua sektor kehidupan yang dibangun atas dasar yang timpang, yaitu tatanan nilai yang menempatkan lakilaki sebagai superior dan perempuan sebagai inferior, inilah yang menjadi fakta sosial di masyarakat hingga hari ini, yang mana posisi kesetaraan atau kesejajaran antara laki-laki dan perempuan cukup lemah.

Semenjak kecil kita telah diajarkan, laki-laki akan diberikan mainan yang memperlihatkan kedinamisan, tantangan, dan kekuatan, seperti mobil-mobilan dan pedang-pedangan, sedangkan perempuan diberikan mainan boneka, pasarpasaran, alat memasak, dan lainnya. Peran-peran yang telah diajarkan kemudian menempatkan salah satu jenis kelamin (baik laki-laki maupun perempuan) pada posisi yang tidak menguntungkan. Karena tidak semua laki-laki mampu bersikap 
tegas dan bisa mengatur, maka laki-laki yang lembut akan dicap banci. Sedangkan jika perempuan lebih berani dan tegas akan disebut tomboi. Tentu saja hal ini menjadi tidak nyaman dan memberikan tekanan.

Semua kekerasan terhadap perempuan juga bersumber dari ketimpangan interaksi antara perempuan dan laki-laki, dimana kekuasaan laki-laki yang diperkuat oleh nilai-nilai patriarkhi yang dianut secara luas ini, mengakibatkan relasi yang timpang antara keduanya, baik itu terjadi di dalam rumah, lingkungan kerja, maupun lingkungan masyarakat pada umumnya. Sayangnya, belum banyak laki-laki ataupun perempuan yang menangkap hubungan tidak adil ini sebagai sebuah bentuk diskriminasi terhadap perempuan.

Munculnya penilaian yang bias terhadap perempuan tersebut pada dasarnya berawal dari tiga asumsi dasar. Pertama, asumsi dogmatis yang secara eksplisit menempatkan perempuan sebagai pelengkap, kedua, dogma bahwa bakat moral etik perempuan lebih rendah, ketiga, pandangan materialistik ideologis yang memandang rendah peran perempuan dalam proses produksi.

Disamping itu, bahwa laki-laki selalu menjadi pemimpin atas perempuan atau lebih berhak memimpin daripada perempuan, ini sudah menjadi ajaran (ortodoksi) yang kokoh di benak masyarakat. Dan ini sangat dipengaruhi oleh dukungan negara yang tidak sungguh-sungguh mengubah budaya patriarkhi, begitu juga dengan pemahaman keagaman yang tekstual dan parsial terhadap beberapa ayat al-Qur'an dan Hadits. Dalil-dalil agama sering dijadikan dalih untuk mempertahankan status quo dimana laki-laki diberikan peran dominan dalam ruang publik, sedangkan perempuan hanya di berikan peran di dunia privat. Laki-laki dianggap lebih pantas memainkan peran dalam masyarakat, sementara perempuan sudah seharusnya terbatas pada sektor domestik.

Pemahaman keagamaan seperti ini telah melestarikan ketimpangan relasi gender di dunia, khususnya Islam, sekian lama. Fakta historis menunjukkan bahwa pemahaman teks-teks suci agama Islam sejak periode klasik berada dalam dominasi laki-laki, sehingga peran perempuan terabaikan. Dari sini para perempuan merasa sudah saatnya berpartisipasi aktif dalam proses pengambilan keputusan. Jika tidak, kondisi perempuan akan terus terpuruk dan perubahan yang menyangkut kepentingan perempuan tidak akan pernah terjadi. 
Oleh karena itu, agenda penting yang mendesak dalam rangka memberikan kesadaran kesetaraan gender yang pertama adalah penilaian ulang dan penafsiran kembali (reinterpretasi), atau pada tahap tertentu perlu dilakukan dekonstruksi terhadap dalil-dalil agama dan pemahaman-pemahaman keagamaan yang cenderung tidak adil dan diskriminatif terhadap perempuan. Dalam hal ini bisa kita ambil contoh mengenai kepemimpinan perempuan dalam Islam. Kepemimpinan perempuan selalu menjadi masalah yang kontroversial dalam Islam. Ini terjadi karena dari satu sisi terdapat sejumlah ayat dan hadits yang secara tekstual mengisyaratkan keutamaan laki-laki untuk menjadi pemimpin meskipun juga terdapat ayat dan hadits yang mengisyaratkan kebolehannya.

Kalau kita mengkaji secara utuh di dalam al-Qur'an dan pada kebijakan Rasulullah maka sesungguhnya Allah swt. memberikan peluang yang sama kepada hamba-Nya tanpa membedakan laki-laki dan perempuan. Bahkan di dalam al-Qur'an telah mengisyaratkan dan sekaligus mengakui keberadaan perempuan sebagai pemimpin politik tertinggi, mengingat bahwa di dalam alQur'an pernah ada tokoh perempuan yang mengendalikan kekuasaan besar dan di sekelilingnya banyak tokoh laki-laki. Tokoh itu diperankan oleh kebesaran Bilqis, kisah panjang penguasa Saba' yang makmur.

Dalam konteks Indonesia, bukan hanya wacana tradisi, adat istiadat, kesenian, ekonomi, ilmu pengetahun, namun juga agama (baca: tafsir keagamaan), ternyata masih perlu telaah mendalam dalam memposisikan perempuan. Hal ini bisa dilihat bahwa perempuan selalu mengalami posisi powerless (ketidakberdayaan), ketika berhadapan dengan tafsir keagamaan. Keberadaan agama dalam pengertian fungsional sesungguhnya dapat menjadi aset besar bagi tumbuh-kembangnya masyarakat.

\section{Menuntut Ilmu dan Akses Pekerjaan}

Agenda pendidikan diyakini sebagai peluang besar untuk memberdayakan perempuan dalam mengurangi ketidaksetaraan terhadap perempuan di berbagai bidang. Dalam hal ini kita bisa mengadopsi pemikiran Qosim Amin yang memperjuangkan pendidikan terhadap perempuan, yaitu klasifikasinya tentang jenis pendidikan ke dalam tiga tingkatan secara berurutan. 
Pertama pendidikan yang wajib bagi setiap orang demi menjaga kehidupannya sendiri dan untuk memenuhi kebutuhan-kebutuhan pribadinya. Kedua, pendidikan yang bermanfaat bagi keluarganya. Dan ketiga, pendidikan yang bermanfaat bagi lingkungan dan masyarakatnya.

Tentu banyak kendala yang dihadapi dalam memperjuangkan pendidikan perempuan. Salah satunya ialah mengubah paradigma bahwa perempuan adalah makhluk yang akal dan agamanya lemah. Paradigma tersebut adalah mitos dan harus dilawan dengan mitos kebalikannya. Perempuan juga harus mendapatkan kebebasan berfikir. Agenda ini sangat penting dilakukan mengingat semakin berkembangnya fenomena pemaksaan cara berfikir dengan mengatasnamakan dogma-dogma agama. Dan yang lebih jauh agenda ini penting mengingat kaum perempuan dipaksa terbiasa menerima pemikiran patriarkal yang dikonstruksi oleh para pemikir laki-laki (fuqaha). Kuatnya bias gender di kalangan masyarakat juga didukung budaya hegemonis dalam berfikir. Karena itu, jika kebebasan berfikir sudah terinternalisasi dalam keberagamaan masyarakat, upaya rekonstruksi dan reinterpretasi pandangan agama yang bias gender akan mudah dilakukan.

Terlalu banyak ayat al-Qur'an dan Hadits Nabi SAW., yang berbicara tentang kewajiban belajar, baik kewajiban tersebut ditujukan kepada laki-laki maupun perempuan. Wahyu pertama dari al-Qur'an adalah perintah membaca atau belajar, Bacalah demi Tuhanmu yang telah menciptakan. Keistimewaan manusia yang menjadikan para malaikat diperintahkan sujud kepadanya adalah karena makhluk ini memiliki pengetahuan. ${ }^{4}$

Baik laki-laki maupun perempuan diperintahkan untuk menimba ilmu sebanyak mungkin, mereka semua dituntut untuk belajar: "Menuntut ilmu adalah kewajiban setiap Muslim (dan Muslimah)." Para perempuan di zaman Nabi SAW menyadari benar kewajiban ini, sehingga mereka memohon kepada Nabi agar beliau bersedia menyisihkan waktu tertentu dan khusus untuk mereka dalam rangka menuntut ilmu pengetahuan. Permohonan ini tentu saja dikabulkan oleh Nabi SAW.

${ }^{4}$ QS. al-Baqarah: 31-33 
Al-Qur'an memberikan pujian kepada generasi $u l i l$ albab ${ }^{5}$, yang berzikir dan memikirkan tentang kejadian langit dan bumi. Zikir dan pemikiran menyangkut hal tersebut akan mengantar manusia untuk mengetahui rahasiarahasia alam raya ini, dan hal tersebut tidak lain dari pengetahuan. Mereka yang dinamai ulil albab tidak terbatas pada kaum laki-laki saja, tetapi juga kaum perempuan. ${ }^{6}$ Ini berarti bahwa kaum perempuan dapat berpikir, mempelajari dan kemudian mengamalkan apa yang mereka hayati dari zikir kepada Allah serta apa yang mereka ketahui dari alam raya ini. Pengetahuan menyangkut alam raya tentunya berkaitan dengan berbagai disiplin ilmu, sehingga dari ayat ini dapat dipahami bahwa perempuan bebas untuk mempelajari apa saja, sesuai dengan keinginan dan kecenderungan mereka masing-masing.

Banyak perempuan yang sangat menonjol pengetahuannya dalam berbagai bidang ilmu pengetahuan dan yang menjadi rujukan sekian banyak tokoh laki-laki. Istri Nabi, Aisyah r.a., adalah seorang yang sangat dalam pengetahuannya serta dikenal pula sebagai kritikus. Sampai-sampai dikenal secara sangat luas ungkapan yang dinisbahkan oleh sementara ulama sebagai pernyataan Nabi Muhammad saw: "Ambillah setengah pengetahuan agama kalian dari al-Humaira' (Aisyah).,"

Rasul SAW tidak membatasi anjuran atau kewajiban belajar hanya terhadap perempuan-perempuan merdeka (yang memiliki status sosial yang tinggi), tetapi juga para budak belian dan mereka yang berstatus sosial rendah. Karena itu, sejarah mencatat sekian banyak perempuan yang tadinya budak belian mencapai tingkat pendidikan yang sangat tinggi. Harus diakui bahwa pembidangan ilmu pada masa awal Islam belum lagi sebanyak dan seluas masa kita dewasa ini. Namun, Islam tidak membedakan antara satu disiplin ilmu dengan disiplin ilmu lainnya, sehingga seandainya mereka yang disebut

\footnotetext{
${ }^{5}$ Ulil Albab adalah orang yang dalam keadaan berdiri, duduk dan berbaring senantiasa berfikir tentang penciptaan Allah. Ulil albab berarti orang yang mempunyai akal berlapis-lapis. Istilah ini sering dijadikan citra diri seorang manusia ideal. Ulil albab memiliki arti beragam yang menunjukkan keluasan maknanya; orang dengan pemikiran mendalam, perasaan yang peka, wawasan yang luas, pengertian yang akurat, juga kebijakan yang mendekati kebenaran. Istilah ini lebih dari lima belas kali digunakan Allah untuk sapaan hamba-hamba-Nya yang tidak hanya melihat peristiwa, melainkan dengan analisis mendalam.

6 "Maka Tuhan mereka memperkenankan permohonannya (dengan berfirman): "Sesunggubnya Aku tidak menyianyiakan amal orang-orang yang beramal di antara kamu, baik laki-laki atau perempuan, (karena) sebagian kamu adalab turunan dari sebagian yang lain...” (QS. Ali Imran: 195).
} 
namanya di atas hidup pada masa kita ini, maka tidak mustahil mereka akan tekun pula mempelajari disiplin-disiplin ilmu yang berkembang dewasa ini.

Dalam hal ini, Syekh Muhammad 'Abduh menulis: "Kalaulah kewajiban perempuan mempelajari hukum-hukum agama kelihatannya amat terbatas, maka sesungguhnya kewajiban mereka untuk mempelajari hal-hal yang berkaitan dengan rumah tangga, pendidikan anak, dan sebagainya yang merupakan persoalan-persoalan duniawi (dan yang berbeda sesuai dengan perbedaan waktu, tempat dan kondisi) jauh lebih banyak daripada soal-soal keagamaan."

Demikian sekilas menyangkut hak dan kewajiban perempuan dalam bidang pendidikan. Kita harus menyadari bahwa kekalahan umat Islam saat ini karena dia ibarat burung yang terbang hanya dengan sebelah sayap. Sumber daya umat Islam yang separuh lagi, yaitu kaum perempuan, belum seterdidik kaum laki-lakinya. Karena itu menjadi kewajiban umat Islam memberi kesempatan berkembang kepada anak-anak perempuan sama seperti anak lakilaki.

Anggapan bahwa perempuan pada dasarnya makhluk yang berkualitas rendah, telah menyeret kita semua, sebagai masyarakat dan sebagai pelaku sejarah, ke dalam kekeliruan yang merugikan diri sendiri dan menjadikan peradaban pincang. Pendidikan untuk perempuan diabaikan, intelektualitas dan spiritualitas mereka diremehkan dan akhirnya suara-suara mereka hanya terdengar samar-samar, sayup-sayup dan terlupakan. Hal ini sesungguhnya sama saja dengan membuang setengah dari sumber daya manusia yang sangat berperan untuk mengisi ruang-ruang peradaban. ${ }^{7}$

Tentunya masih banyak lagi yang dapat dikemukakan menyangkut hakhak kaum perempuan dalam berbagai bidang. Namun, kesimpulan akhir yang dapat ditarik adalah bahwa perempuan, sebagaimana sabda Rasul SAW, adalah Syaqa'iq al-Rijal (saudara-saudara sekandung kaum laki-laki) sehingga kedudukannya serta hak-haknya dapat dikatakan sama. Kalaupun ada yang membedakan, maka itu hanyalah akibat fungsi dan tugas-tugas utama yang dibebankan Tuhan kepada masing-masing jenis kelamin itu, sehingga perbedaan

${ }^{7}$ Dr. Zulkarnaini Abdullah, Mengapa Harus Perempuan?, Yogyakarta: ar-Ruzz, 2005,69. 
yang ada tidak mengakibatkan yang satu merasa memiliki kelebihan atas yang lain. ${ }^{8}$

Kita lanjutkan kepada hak-hak perempuan dalam akses memilih pekerjaan. Kalau kita kembali menelaah keterlibatan perempuan dalam pekerjaan pada masa awal Islam, maka tidaklah berlebihan jika dikatakan bahwa Islam membenarkan mereka aktif dalam berbagai aktivitas. Para perempuan boleh bekerja dalam berbagai bidang, di dalam ataupun di luar rumahnya, baik secara mandiri atau bersama orang lain, dengan lembaga pemerintah maupun swasta, selama pekerjaan tersebut dilakukannya dalam suasana terhormat, sopan, serta selama mereka dapat memelihara agamanya, serta dapat pula menghindari dampak-dampak negatif dari pekerjaan tersebut terhadap diri dan lingkungannya.

Pekerjaan dan aktivitas yang dilakukan oleh perempuan pada masa Nabi cukup beraneka ragam, sampai-sampai mereka terlibat secara langsung dalam peperangan-peperangan, bahu-membahu dengan kaum laki-laki. Dalam bidang perdagangan, nama istri Nabi yang pertama, Khadijah binti Khuwailid, tercatat sebagai seorang yang sangat sukses. Demikian juga Qilat Ummi Bani Anmar yang tercatat sebagai seorang perempuan yang pernah datang kepada Nabi untuk meminta petunjuk-petunjuk dalam bidang jual-beli. Nabi memberi petunjuk kepada perempuan ini dengan sabdanya: Apabila Anda akan membeli atau menjual sesuatu, maka tetapkanlah harga yang Anda inginkan untuk membeli atau menjualnya, baik kemudian Anda diberi atau tidak. (Maksud beliau jangan bertele-tele dalam menawar atau menawarkan sesuatu).

Demikian sedikit dari banyak contoh yang terjadi pada masa Rasul SAW dan sahabat beliau menyangkut keikutsertaan perempuan dalam berbagai bidang usaha dan pekerjaan. Di samping yang disebutkan di atas, perlu juga digaris bawahi bahwa Rasul SAW banyak memberi perhatian serta pengarahan kepada perempuan agar menggunakan waktu sebaik-baiknya dan mengisinya dengan pekerjaan-pekerjaan yang bermanfaat.

\footnotetext{
8"Dan janganlah kamu iri hati terhadap apa yang dikaruniakan Allab kepada sebagian kamu lebih banyak dari sebagian yang lain. (karena) Bagi orang laki-laki ada bagian dari pada apa yang mereka usabakan, dan bagi para wanita (pun) ada bagian dari apa yang mereka usahakan, dan mohonlab kepada Allah sebagian dari karuniaNya. Sesunggubnya Allab Maha Mengetabui segala sesuatu." (QS. al-Nisa': 32)
} 
Tentu saja tidak semua bentuk dan ragam pekerjaan yang terdapat pada masa kini telah ada pada masa Nabi saw. Namun, sebagaimana telah diuraikan di atas, ulama pada akhirnya menyimpulkan bahwa perempuan dapat melakukan pekerjaan apapun selama ia membutuhkannya atau pekerjaan itu membutuhkannya dan selama norma-norma agama dan susila tetap terpelihara.

\section{Partisipasi Politik}

Setelah Nabi SAW wafat, aktivitas perempuan berangsur-angsur surut, hingga memucak pada peristiwa keterlibatan Siti Aisyah (istri Nabi) dalam memimpin perang unta melawan Khalifah Ali bin Abi Thalib, dimana peristiwa itu kontroversial dikalangan pemikir Islam klasik. Ada satu pendapat yang mengatakan, tindakan itu merupakan ijtihad Aisyah sehingga tidak berdampak politis apa-apa dan ia mendapatkan satu pahala. Ada juga sebagian kalangan yang mengatakan, peristiwa itu biang perpecahan umat Islam, sehingga menjadi legitimasi terhadap perempuan Islam untuk tidak berkiprah di bidang politik.

Puncak pembatasan terjadi pada masa Kekhalifahan Daulah Islamiyah dan Abbasiyah. Pada dinasti Umayyah masa Khalifah al-Walid II (743-744 M), perempuan pertama kalinya ditempatkan di Harem-Harem dan tidak punya andil dalam keterlibatan publik. Gaung keterlibatan perempuan, pada masa ini, hampir tidak terdengar. Pada akhir kekhalifahan Abbasiyah yaitu pada pertengahan abad ke-13 M, sistem Harem telah tegak kokoh.

Salah satu ayat yang seringkali dikemukakan oleh para pemikir Islam dalam kaitan dengan hak-hak politik kaum perempuan adalah yang tertera dalam surat al-Taubah ayat 71; "Dan orang-orang yang beriman, lelaki dan perempuan, sebagian mereka (adalah) menjadi penolong bagi sebagian yang lain. mereka menyuruh (mengerjakan) yang ma'ruf, mencegah dari yang munkar, mendirikan shalat, menunaikan zakat dan mereka taat pada Allah dan Rasul-Nya. Mereka itu akan diberi rahmat oleh Allah; Sesungguhnya Allah Maha Perkasa lagi Maha Bijaksana.”

Secara umum, ayat di atas dipahami sebagai gambaran tentang kewajiban melakukan kerja sama antar laki-laki dan perempuan dalam berbagai bidang kehidupan yang dilukiskan dengan kalimat menyuruh mengerjakan yang ma'ruf dan mencegah yang munkar. Kata awliya', dalam pengertiannya, mencakup 
kerja sama, bantuan dan penguasaan, sedang pengertian yang dikandung oleh "menyuruh mengerjakan yang ma'ruf" mencakup segala segi kebaikan atau perbaikan kehidupan, termasuk memberi nasihat (kritik) kepada penguasa. Dengan demikian, setiap laki-laki dan perempuan muslimah hendaknya mampu mengikuti perkembangan masyarakat agar masing-masing mereka mampu melihat dan memberi saran (nasihat) dalam berbagai bidang kehidupan.

Keikutsertaan perempuan bersama dengan laki-laki dalam kandungan ayat di atas tidak dapat disangkal, sebagaimana tidak pula dapat dipisahkan kepentingan perempuan. Kepentingan (urusan) kaum Muslim mencakup banyak sisi yang dapat menyempit atau meluas sesuai dengan latar belakang pendidikan seseorang, tingkat pendidikannya. Dengan demikian, kalimat ini mencakup segala bidang kehidupan termasuk bidang kehidupan politik.

Hak-hak politik perempuan tentunya akan terkait dengan hak asasi manusia secara umum. ${ }^{9}$ Hak asasi ini dimiliki tanpa membedakan dasar bangsa, ras, agama, begitu pula jenis kelamin, karena dasar hak asasi ini adalah bahwa manusia memperoleh kesempatan untuk berkembang sesuai dengan bakat dari cita-citanya. ${ }^{10}$ Di sisi lain, al-Qur'an juga mengajak umatnya (laki-laki dan perempuan) untuk bermusyawarah, melalui pujian Tuhan kepada mereka yang selalu melakukannya. ${ }^{11}$

Ayat ini dijadikan pula sebagai dasar oleh banyak ulama untuk membuktikan adanya hak berpolitik bagi setiap laki-laki dan perempuan. Syura (musyawarah) telah merupakan salah satu prinsip pengelolaan bidang-bidang kehidupan bersama menurut al-Qur'an, termasuk kehidupan politik, dalam arti setiap masyarakat dalam kehidupan bersamanya dituntut untuk senantiasa mengadakan musyawarah.

Atas dasar ini, dapat dikatakan bahwa setiap laki-laki maupun perempuan memiliki hak tersebut, karena tidak ditemukan satu ketentuan agama

\footnotetext{
${ }^{9} \mathrm{Hak}$ untuk berpolitik artinya hak untuk berpendapat, untuk menjadi anggota lembaga perwakilan, dan untuk memperoleh kekuasaan seperti memimpin lembaga formal, organisasi, partai, bahkan kepala pemerintahan. Muhammmad Anis Qasim, Perempuan dan Kekuasaan; Menelusuri Hak Politik dan Persoalan Gender dalam Islam. Bandung: Zaman. 1998, 36.

${ }^{10}$ Miriam Budiardjo. Dasa-dasar Ilmu Politik. Jakarta: Gramedia, 1998, 120.

11 "Dan (bagi) orang-orang yang menerima (mematubi) seruan Tuhannya dan mendirikan shalat, sedang urusan mereka (diputuskan) dengan musyawarah antara mereka; dan mereka menafkabkan sebagian dari rezki yang Kami berikan kepada mereka." (al-Syura: 38)
} 
pun yang dapat dipahami sebagai melarang keterlibatan perempuan dalam bidang kehidupan bermasyarakat -termasuk dalam bidang politik. Bahkan sebaliknya, sejarah Islam menunjukkan betapa kaum perempuan terlibat dalam berbagai bidang kemasyarakatan, tanpa kecuali. ${ }^{12}$

Sementara, pakar agama Islam menjadikan baiat para perempuan itu sebagai bukti kebebasan perempuan untuk menentukan pilihan atau pandangannya yang berkaitan dengan kehidupan serta hak mereka. Dengan begitu, mereka dibebaskan untuk mempunyai pilihan yang berbeda dengan pandangan kelompok-kelompok lain dalam masyarakat, bahkan terkadang berbeda dengan pandangan suami dan ayah mereka sendiri.

Harus diakui bahwa ada sementara ulama yang menjadikan firman Allah dalam surat al-Nisa' ayat 34, 'Laki-laki adalah pemimpin perempuanperempuan..." sebagai bukti tidak bolehnya perempuan terlibat dalam persoalan politik. Karena -kata mereka- kepemimpinan berada di tangan laki-laki, sehingga hak-hak berpolitik perempuan pun telah berada di tangan mereka. Pandangan ini bukan saja tidak sejalan dengan ayat-ayat yang dikutip di atas, tetapi juga tidak sejalan dengan makna sebenarnya yang diamanatkan oleh ayat yang disebutkan itu.

Ayat al-Nisa' 34 itu berbicara tentang kepemimpinan laki-laki (dalam hal ini suami) terhadap seluruh keluarganya dalam bidang kehidupan rumah tangga. Kepemimpinan ini pun tidak mencabut hak-hak istri dalam berbagai segi, termasuk dalam hak pemilikan harta pribadi dan hak pengelolaannya walaupun tanpa persetujuan suami.

Kenyataan sejarah menunjukkan sekian banyak di antara kaum perempuan yang terlibat dalam soal-soal politik praktis. Ummu Hani misalnya, dibenarkan sikapnya oleh Nabi Muhammad SAW. ketika memberi jaminan keamanan kepada sementara orang musyrik (jaminan keamanan merupakan salah satu aspek bidang politik). Bahkan istri Nabi Muhammad SAW. sendiri,

\footnotetext{
${ }^{12} \mathrm{Al}-Q u r$ 'an juga menguraikan permintaan para perempuan pada zaman Nabi untuk melakukan baiat (janji setia kepada Nabi dan ajarannya), sebagaimana disebutkan dalam al-Qur'an; "Hai Nabi, apabila datang kepadamu perempuan-perempuan yang beriman untuk mengadakan janji setia, babwa mereka tiada akan menyekutukan Allab, tidak akan mencuri, tidak akan berzina, tidak akan membunub anak-anaknya, tidak akan berbuat dusta yang mereka ada-adakan antara tangan dan kaki mereka dan tidak akan mendurbakaimu dalam urusan yang baik, maka terimalah janji setia mereka dan mobonkanlah ampunan kepada Allah untuk. mereka. Sesunggubnya Allah Maha Pengampun lagi Maha Penyayang.” (QS. Al-Mumtahanah: 12)
} 
yakni 'Aisyah r.a., memimpin langsung peperangan melawan 'Ali ibn Abi Thalib yang ketika itu menduduki jabatan Kepala Negara. Isu terbesar dalam peperangan tersebut adalah soal suksesi setelah terbunuhnya Khalifah Ketiga, Utsman r.a.

Peperangan itu dikenal dalam sejarah Islam dengan nama Perang Jamal (656 M). Keterlibatan 'Aisyah r.a. bersama sekian banyak sahabat Nabi dan kepemimpinannya dalam peperangan itu, menunjukkan bahwa beliau bersama para pengikutnya itu menganut paham kebolehan keterlibatan perempuan dalam politik praktis sekalipun.

\section{Kesetaraan Gender}

Pembahasan mengenai kesetaraan gender dan bagaimana Islam memiliki semangat kesetaraan gender di dalam nilai-nilainya, bukanlah suatu hal yang baru. Namun setiap kali pembahasan ini muncul, banyak pula pihak yang bertanya-tanya, apakah sebenarnya yang diinginkan perempuan? Padahal masalah gender ini bukanlah semata-mata masalah perempuan, tetapi masalah kesalahan pola pikir yang berakibat pada pandangan yang salah terhadap teks.

Konsep tentang perempuan sering digambarkan dalam bingkai yang terlalu romantis oleh sebagian buku-buku Islam. Perempuan digambarkan sebagai makhluk yang lemah lembut sehingga perlu mendapat perlindungan dari ayah atau suaminya, bahkan adik laki-lakinya pun disuruh untuk melindungi kakaknya yang perempuan. Mengapa gambaran seperti ini terlalu romantis? Karena "perlindungan" yang didapat perempuan di lapangan tidak lebih dari domestifikasi dan dominasi. Lemah lembut juga lebih jauh diartikan sebagai lemah akal pikirannya (sering dipahami; bodoh dan tidak mampu mengambil keputusan) serta lemah imannya (sering dibaca; lebih dekat dengan perbuatan dosa dan atau mempengaruhi orang lain untuk berbuat dosa). Pada akhirnya, persoalan perempuan yang berakar pada mitos-mitos patriarkhis terus terlestarikan. Parahnya, mitos-mitos tersebut kemudian dilegitimasi oleh agama.

Begitupun dengan pemahaman terhadap hadits tentang perempuan yang akan dilaknat malaikat ketika menolak berhubungan seks dengan suaminya, perempuan harus selalu meminta ijin pada suaminya, bahkan untuk keinginan melakukan puasa sunnah, atau hal-hal lain seputar kewajiban perempuan untuk 
taat yang terkesan sangat berlebihan. Implikasinya, seorang isteri harus mematuhi suaminya, jika diperintahkan untuk tidak meninggalkan rumah, tidak bekerja diluar rumah, tidak mengunjungi teman-temannya, maka hal itu haram dilakukan. Bahkan di beberapa negara Islam, wanita, dilarang menyetir mobil sendiri.

Secara konsep, keberadaan agama sejatinya menjadi wacana alternatif bagi terciptanya realitas tanpa kekerasan khususnya terhadap perempuan. Akan tetapi rupanya aksi di lapangan tidak mencitrakan demikian. Sehingga bagi seseorang yang taat menjalankan ajaran agamanya, rasanya wajar bila muncul pertanyaan, mengapa Tuhan membiarkan semua ini terjadi? Mengapa agama tidak bersahabat dengan perempuan?

Sesungguhnya Teks Suci al-Qur'an tidak perlu lagi diragukan kebenarannya. Namun ketika teks tersebut hidup di masyarakat, terjadi banyak terdistorsi. Distorsi tersebut terutama disebabkan pola pikir patriarkhis akibat dominasi laki-laki yang telah mengakar kuat di dalam masyarakat. Pola pikir yang salah ini ternyata berakar jauh pada campur aduknya pemahaman terhadap kisah penciptaan dan kejatuhan Adam dan Hawa. Bahwa Hawa diciptakan dari tulang rusuk Adam dan Hawa yang menyebabkan kedua manusia ini terjatuh dan terusir dari surga, sama sekali tidak ada dalam teks Islam. Oleh karena itu, tidak ada alasan bagi muslim laki-laki maupun perempuan lebih rendah, lebih bodoh dan suka menggoda. Hal itu perlu kita hapus dan kita lupakan dalam ingatan sejarah.

Agama Islam hadir di tengah-tengah masyarakat Arab yang sarat dengan praktik dan budaya diskriminatif dan memarjinalkan perempuan. Tradisi masyarakat saat itu, perempuan dipandang sebagai manusia kelas dua dan manusia yang bermartabat rendah, tidak berharga, dan tidak memiliki hak apaapa atas hidup mereka. Karena itu hak-hak kaum perempuan saat itu sepenuhnya berada di tangan laki-laki.

Demikian pula pada umumnya dunia dikenal sebagai pelaku-pelaku sistem patriarkhi, lebih mengutamakan kaum laki-laki. Kaum laki-laki menjadi tempat ketergantungan mereka dalam segala aspek kehidupan kaum perempuan. 
Hal ini dapat kita saksikan misalnya kesaksian sahabat dan diungkapkan dalam sebuah kalimat yang tegas dan realitas atas pengalaman yang dialaminya.

Lebih dari itu, perempuan bukan saja dihinakan, diremehkan tapi juga ditindas dalam arti selalu mendapat tindakan kekerasan. Bahkan sebagian dari masyarakat pada saat itu perempuan dianggap sebagai pembawa bahaya dan malapetaka, memalukan, karena itu harus dimusnahkan.

Sahabat 'Umar ibn Khattab menjadi saksi atas sistem tersebut. Beliau berkata, "Sejak lama kami bangsa Arab tidak pernah mengakui hak-hak kaum perempuan. Ketika Islam datang dan menyebut nama mereka, saya baru sadar bahwa mereka (kaum perempuan) memiliki hak-haknya secara otonom.”

Sumber Islam melalui kitab sucinya tersebut dalam ungkapan-ungkapan di atas, dan sejumlah teks-teks yang lain pada awalnya telah berusaha melakukan pembongkaran terhadap wacana ideologis yang berkembang di saat itu. Sebuah ideologi yang sangat kental dan tampak patriarkhis, sepenuhnya dapat dikatakan diskriminatif dan sarat dengan nilai-nilai dan bentuk-bentuk kekerasan.

Pandangan egalitarisme Islam dan penolakannya atas praktik-praktik dalam kaitannya relasi antara laki dan perempuan telah dibicarakan secara luas dan gamblang oleh teks-teks suci Islam. Al-Qur'an dan Hadits dengan tegas menyatakan bahwa laki dan perempuan keduanya memiliki kesamaan penuh contohnya dalam nilai religius, ${ }^{13}$ demikian pula dalam kehidupan sosial kemasyarakatan. ${ }^{14}$

Memperjuangkan kesetaraan bukanlah berarti mempertentangkan dua jenis kelamin, laki-laki dan perempuan. Sekali lagi bukanlah mempertentangkan laki-laki dan perempuan Tetapi, ini lebih kepada upaya membangun hubungan (relasi) yang setara. Kesempatan harus terbuka sama luasnya bagi laki-laki atau perempuan, sama pentingnya, untuk mendapatkan pendidikan, makanan yang bergizi, kesehatan, kesempatan kerja, termasuk terlibat aktif dalam organisasi sosial-politik dan proses-proses pengambilan keputusan.

Hal ini mungkin bisa terjadi jika mitos-mitos seputar citra (image) menjadi "laki-laki" dan "perempuan" didekonstruksi lebih dulu. Sebagai laki- 
laki ataupun perempuan, kita harus menyadari bahwa kita adalah pemain dalam kondisi (hubungan) ini. Jadi, untuk bisa mengubah kondisi-kondisi yang tidak menguntungkan ini, maka baik sebagai laki-laki ataupun perempuan keduanya harus terlibat.

Meskipun banyak korban dari sistem yang ada sekarang adalah perempuan, bukan berarti usaha-usaha untuk mengubahnya adalah tanggung jawab perempuan semata. Karena ini menyangkut sistem sosial-budaya, tentu saja kesepakatan harus dibangun baik sebagai perempuan ataupun laki-laki.

Hal utama yang mesti kita lakukan adalah membangun kesadaran diri. Ini bisa dilakukan melalui pendidikan yang sensitif gender. Karena peran-peran yang menimbulkan relasi tak setara juga terjadi akibat pengajaran dan sosialisasi, cara mengubahnya juga melalui pengajaran dan sosialisasi baru. Kita bisa melakukan pelatihan atau diskusi secara kritis.

Kita harus membangun pemahaman dan pendekatan baru bahwa ini juga menyangkut laki-laki. Tidak mungkin akan terjadi perubahan jika laki-laki tidak terlibat dalam usaha ini. Perempuan bisa dilatih untuk lebih aktif, berani, dan mampu mengambil keputusan, sedangkan laki-laki pun harus sadar untuk menghormati dan menghargai kemampuan perempuan dan mau bermitra untuk maju.

Salah satu cara untuk memulai perubahan adalah dengan mengungkapkan hal-hal yang menimbulkan tekanan atau diskriminasi. Cara terbaik adalah bersuara dan membicarakannya secara terbuka dan bersahabat. Harus ada media untuk membangun dialog untuk menyepakati cara-cara terbaik membangun relasi yang setara dan adil antar jenis kelamin.

Karena ini menyangkut sistem sosial-budaya yang besar, hasil dialog atau kesepakatan untuk perubahan yang lebih baik harus kita kampanyekan sehingga masyarakat dapat memahami idenya dan dapat memberikan dukungan yang dibutuhkan. Termasuk di dalamnya mengubah cara pikir dan cara pandang masyarakat melihat "laki-laki" dan "perempuan". Masyarakat harus memahami bahwa beberapa sistem sosial-budaya yang merupakan produk cara berpikir sering kali tidak berpihak, menekan, dan menghambat peluang perempuan untuk memiliki kesempatan yang sama dengan laki-laki. 
Tidak ada cara terbaik untuk merealisasikan kondisi yang lebih baik selain menerapkan pola relasi yang setara dalam kehidupan kita masing-masing. Tentu saja semua harus dimulai dari diri kita sendiri, lalu kemudian kita dorong orang terdekat kita untuk menerapkannya.

Namun, kenyataan di lapangan menunjukkan bahwa perbincangan tentang kesetaraan gender masih banyak menimbulkan polemik. Image perjuangan untuk kesetaraan gender harus digeser supaya masyarakat tidak phobia. Menurut Dr. Musdah Mulia, masyarakat menjadi phobia dengan istilah kesetaraan gender karena; pertama, konsep gender berasal dari barat sehingga serta merta dianggap bertentangan dengan Islam. Kedua, wacana kesetaraan gender bicara tentang hal-hal yang privat dalam kehidupan manusia. Dan ketiga, wacana kesetaraan gender menggugat hal-hal yang mapan yang sudah lama memberikan privilige pada kelompok masyarakat tertentu. Alasan-alasan ini menunjukkan bahwa agama akhirnya hanya digunakan untuk melegitimasi budaya dan kemapanan, sehingga penerapannya tidak holistik.

Kesetaraan bukan semata-mata persoalan keinginan dan tuntutan perempuan, tetapi persoalan seluruh muslim untuk berani mengubah pola pikir dan mendobrak kemapanan, demi menegakkan keadilan seperti tuntunan agamanya. Dalam Islam, persoalan gender, merupakan contoh nyata betapa antara teks kitab suci, penafsiran terhadapnya, dan konteks sosial yang melingkupi, sering terjadi benturan-benturan dan ketegangan. Hingga saat ini, keadilan gender, kesetaraan laki-laki dan perempuan, di masyarakat muslim masih beragam. Keberagaman ini penting untuk dikritisi, karena sama-sama mengklaim dirinya berpegang pada kitab suci al-Qur`an.

Rekonstruksi dan reinterpretasi teks-teks agama hendaknya juga memberikan keabsahan bagi perempuan untuk menentukan kemauannya dan mereformulasi pola relasi dan kuasa antara laki-laki dan perempuan baik lingkup pribadi, keluarga dan masyarakat. Jika ketidakadilan, diskriminasi, penindasan dan kekerasan terhadap perempuan meliputi basis kesadaran dan konstruksi nilai 
yang sangat luas dan kompleks, maka dimensi agama justru menjadi bagian yang sangat penting. ${ }^{15}$

Tidak ada seorangpun yang membantah bahwa agama-agama dihadirkan Tuhan di tengah-tengah manusia untuk mewujudkan kemaslahatan, kasih sayang, hak dan keadilan yang tidak pandang suku, ras dan jenis kelamin. Konsep rahmatan lil 'alamin menegaskan komitmen ini. Atas dasar ini semua pemikiran, tindakan dan sistem apapun yang melegitimasi praktik penindasan, marginalisasi, diskriminasi dan misoginis terhadap siapapun, harus ditolak atas nama agama dan kemanusiaan.

\section{PENUTUP}

Dengan menekuni persoalan-persoalan gender, ada beberapa permasalahan tafsiran keagamaan yang dianggap strategis agar segera mendapat perhatian untuk dilakukan kajian, terutama yang menyangkut persoalan subordinasi kaum perempuan akibat penafsiran yang meletakkan kaum perempuan dalam kedudukan dan martabat yang subordinatif terhadap kaum laki-laki. Padahal, pada dasarnya semangat hubungan laki-laki dan perempuan dalam Islam bersifat adil (equal). Oleh karena itu subordinasi kaum perempuan merupakan suatu keyakinan yang berkembang di masyarakat sudah tidak sesuai atau bertentangan dengan semangat keadilan. Al-Qur'an sendiri tidak pernah membedakan laki-laki dan perempuan. ${ }^{16}$

Pemahaman yang bias gender selain meneguhkan subordinasi kaum perempuan, juga membawa akibat pada persoalan waris dan kesaksian, di mana nilai kaum perempuan dianggap separuh dari kaum laki-laki. Untuk membahas ini perlu dilakukan analisis konteks sosial terhadap struktur sosio-kultural pada saat ayat tersebut diturunkan, sehingga pemahaman masalah waris dan kesaksian tidak bertentangan dengan prinsip keadilan yang disampaikan dalam ayat-ayat di atas. Umumnya mereka yang menekuni masalah keadilan gender tidak melihat angka pembagiannya, melainkan semangat keadilannya. Sehingga demi

\footnotetext{
${ }^{15}$ Khofifah Indar Parawansa, "Pemberdayaan Perempuan melalui Rekonstruksi Pemahaman Agama" dalam Pemberdayaan Perempuan melalui Pemahaman Ajaran Agama (Upaya Rekonstruksi Teks Agama). Surabaya: PSG IAIN Sunan Ampel, 2003, 98.

${ }^{16}$ (QS. al-Taubah: 71); (Ali 'Imran: 195); (al-Nahl: 97)
} 
mencapai keadilan, merubah angka yang sesuai dengan sistem dan struktur sosial dewasa ini pun perlu dilakukan.

Seorang feminis pernah mengatakan, "Bahwa perjuangan perempuan adalah perjuangan yang paling sulit dan paling lama, berbeda dengan perjuangan kemerdekaan atau rasial. Karena musuh perempuan seringkali tidak berbentuk dan bersumber dalam kamar-kamar pribadi. Oleh karena itu, perjuangan perempuan masih dibutuhkan, mungkin masih berabad-abad di kemudian hari. Yang jelas sampai kami berdiri tegap seperti manusia lainnya yang di ciptakan Tuhan."

Syeikh Mahmud Syaltut berpesan, "Tabiat kemanusiaan antara laki-laki dan perempuan hampir dapat (dikatakan) sama. Allah telah menganugerahkan kepada perempuan sebagaimana menganugerahkan kepada laki-laki. Kepada mereka berdua dianugerahkan Tuhan potensi dan kemampuan yang cukup untuk memikul tanggung jawab dan yang menjadikan kedua jenis kelamin ini dapat melaksanakan aktivitas-aktivitas yang bersifat umum maupun khusus. Karena itu, hukum-hukum Syari'at pun meletakkan keduanya dalam satu kerangka. Yang ini (laki-laki) menjual dan membeli, mengawinkan dan kawin, melanggar dan dihukum, menuntut dan menyaksikan, dan yang itu (perempuan) juga demikian, dapat menjual dan membeli, mengawinkan dan kawin, melanggar dan dihukum serta menuntut dan menyaksikan."

Kalau selama ini masih terjadi diskriminasi dan marginalisasi oleh beberapa pihak atas pihak lain, yang itu sangat bertentangan dengan konsep rahmatan lil 'alamin, pada sisi ini kita harus berangkat melakukan rekonstruksi dan penafsiran ulang terhadap ajaran agama. 


\section{BIBLIOGRAFI}

Abdullah, Zulkarnaini. Mengapa Harus Perempuan?. Yogyakarta: ar-Ruzz, 2005.

Ahmed, Laela. Perempuan dan Gender dalam Islam. Akar-akar Historis Perdebatan Modern. Jakarta: Lentera, 2000.

Ali, Muhammad ibn Muhammad. Hijab. Yogyakarta: Pustaka Sufi, 2002.

Al-Nawawi, Muhammad ibn 'Umar. Syarh 'Uqud al-Lujjayn fi Bayan Huquq alZawjayn. Semarang: Thaha Putra.

'Uqud al-Lujjayn fi Bayan al-Huquq al-Zaujain. Surabaya: al-Hidayah.

Baidhawy, Zakiyuddin (ed.). Wacana Teologi Feminis. Yogyakarta: Pustaka Pelajar, 1997.

Beauvoir, Simone De. The Second Sex. New York: Vintage Books, 1974.

Buckley, Thomas and Alma Gottlies (ed.). Blood Magic, the Antropology of Menstruation. Berkeley, Los Angeles, London: University of California Press, 1998.

Chittick, William C., "Mitos Turunnya Adam dalam Rawh al-Arwah Ahmad Sam'ani” dalam Warisan Sufi (Buku Pertama). Yogyakarta: Pustaka Sufi, 2005.

Engineer, Asghar Ali. Pembebasan Perempuan. Yogyakarta: LkiS, 2003.

Fakih, Mansour. Analisis Gender dan Transformasi Sosial. Yogyakarta: Pustaka Pelajar, 1999.

Fauzi, Moch. Sony. "Kekerasan Terhadap Perempuan (Sebuah Fenomena Sosial Keagamaan)" dalam Jurnal el-Harakah No. 56/XXII/Januari-Maret 2001.

Firdaus, Akhol. Sindrom Iri Penis, Sketsa Kritik Nalar Feminisme. Surabaya: Pinggir Indonesia, 2005.

Freidan, Betty. The Feminine Mystique. New York: Dell, 1974.

Fudhaili,Ahmad. Perempuan di Lembaran Suci; kritik Atas Hadis-Hadis Sahih. Yogyakarta: Pilar Religia, 2005.

Ghanim, Muhammad Salman. 2004. Kritik Ortodoksi; Tafsir Ayat Ibadah, Politik Dan Feminisme. Yogyakarta: LkiS, 2004. 
Ghazali, Abdul Moqsith.. Tubuh, Seksualitas dan Kedaulatan Perempuan. Yogyakarta: LkiS, 2002.

Hasyim, Syafiq (ed.). Menakar Harga Perempuan. Bandung: Mizan, 1999.

Ismail, Nurjannah. Perempuan Dalam Pasungan. Yogyakarta: LKiS, 2003.

Isroqunnajah. "Dorsumsisi, Awal Kekerasan Terhadap Perempuan", dalam Jurnal el-Harakah No. 56/XXII/Januari-Maret 2001.

Istiadah. Membangun Bahtera Keluarga Yang Kokoh. Jakarta: Gramedia, 2004.

Jawad, Haifaa A. Perlawanan Perempuan: Sebuah Pendekatan Otentik Religius. Malang: Cendekia Paramulya, 2002.

Mas'udi, Masdar F. "Tindak Kekerasan terhadap Perempuan dalam Wacana Islam" dalam HAM dan Kekerasan terhadap Perempuan di Aceh. Banda Aceh: Flower Aceh, 1999.

Islam dan Hak-Hak Reproduksi Perempuan. Bandung: Mizan, 1997.

Megawangi, Ratna. Membiarkan Berbeda? Sudut Pandang Baru tentang Relasi Gender. Bandung: Mizan, 1999.

--Menengok Kontroversi Peran Perempuan dalam Politik. Surabaya: Dunia Ilmu, 1997.

Mernissi, Fatima dan Riffat Hassan. Setara di Hadapan Allah, Relasi Laki-laki dan Perempuan dalam Tradisi Islam Pasca Patriarkhi. Yogyakarta: LSPPA-Yayasan Prakarsa, 1995.

Mitchell, Juliet. Psychoanalysis and Feminism. New York: Vintage Books, 1974.

Moghissi, Haideh.Feminisme dan Fundamentalisme Islam. Yogyakarta: LKiS, 2005.

Mufidah Ch., Paradigma Gender. Malang: Bayumedia, 2003.

Muhammad, Hussein.Islam Agama Ramah Perempuan. Yogyakarta: LKiS, 2004.

Muhsin, Amina Wadud. Perempuan di dalam al-Qur'an. Bandung: Pustaka, 1999.

Musdalifah. All About Perempuan. Jakarta: Arina, 2005.

Parawansa, Khofifah Indar, "Pemberdayaan Perempuan melalui Rekonstruksi Pemahaman Agama" dalam Pemberdayaan Perempuan melalui 
Pemahaman Ajaran Agama (Upaya Rekonstruksi Teks Agama). Surabaya: PSG IAIN Sunan Ampel, 2003.

--Perempuan Dalam Islam. Bandung: Pustaka Britama, 1991.

Rahman, Fazlur. Major Themes of the Qur'an. Chicago: Bibliotheca Islamica, 1980.

Rahmat, Jalaludin "Dari Psikologi Androsentris ke Psikologi Feminis: Membongkar Mitos-Mitos Tentang Perempuan," dalam Jurnal Ulumul Qur'an, No. 5 \& 6, Vol. 5, 1994.

Roqib, Moh., Pendidikan Perempuan. Yogyakarta: Gama Media, bekerjasama dengan STAIN Purwokerto Press, 2003.

Rusyd, Ibn. Bidayatul Mujtahid wa al-Nihayah al-Muqtashid. Semarang: AsSyifa, 1990.

Subhan, Zaitunah. Tafsir Kebencian; Studi Bias Jender dalam Tafsir al-Qur'an. Yogyakarta: LKiS, 1999.

Syarifuddin, Didin. "Argumen Supremasi atas Perempuan: Penafsiran klasik QS. al-Nisa': 34," dalam Jurnal Ulumul Qur'an, No. 5 \& 6, Vol. 5, 1994.

Umar, Nasaruddin "Paradigma Baru Teologi Perempuan" dalam Pemberdayaan Perempuan melalui Pemahaman Ajaran Agama (Upaya Rekonstruksi Teks Agama). Surabaya: PSG IAIN Sunan Ampel, 2003.

Argumen Kesetaraan Gender Perspektif al-Qur'an. Jakarta; Paramadina, 2003.

Yazid, Muhammad (ed.). Pemberdayaan Perempuan Melalui Pemahaman Ajaran Agama (Upaya Rekonstruksi Teks Agama). Surabaya: PSG IAIN Surabaya, 2003. 